\title{
Metafor Kerapan Sapi dalam Tata Kelola Perusahaan dari Sudut Pandang Teori Stewardship
}

\author{
Mohammad Baqir Ainun ${ }^{*}$ \\ ${ }^{1}$ Fakultas Ekonomi dan Bisnis Universitas Wiraraja \\ JI. Raya Pamekasan - Sumenep Panitian Utara Sumenep 69451 Jawa Timur \\ *Email: ainunbaqir@gmail.com
}

Naskah diterima 10 Agustus 2021, Revisi 15 September 2021, Terbit 29 Oktober 2021

\begin{abstract}
DOI: doi.org/10.21107/pamator.v14i2.10801

This study aims to explain how kerapan sapi culture can describe corporate governance from the point of view of stewardship theory. Stewardship theory states that managers will carry out their duties and responsibilities in the interests of the organization and shareholders. In this theory, the manager will put aside his personal interests. Kerapan sapi is a Madurese culture that competes for the running speed of a pair of cows using pangonong and kaleles as a place for the tokang tongko' to stand to control the cows. Tokang tongko' is a party that has an important role in creating an effective and efficient running speed of Sapi Kerap in order to become a winner, just like a company manager who is the authorized party to manage the company effectively and efficiently in order to be able to compete with competitors. Tokang tongko' is assumed to have a trustworthy, honest, and responsible nature for the trust that has been given by the owner of the cow, which is often in accordance with the theory of stewardship. Tokang tongko' will take actions in accordance with the interests of sapi kerap owners, like a manager who carries out his duties and responsibilities in the interests of shareholders.
\end{abstract}

Key words: kerapan sapi, corporate governance, stewardship theory

\section{PENDAHULUAN}

Pada tahun 1980-an, perusahaanperusahaan di Inggris dan Amerika Serikat diguncang dengan adanya skandal-skandal besar yang timbul akibat adanya keserakahan dan hostile take over. Peristiwa ini pada akhirnya menimbulkan kesadaran dan perhatian lebih terhadap pentingnya penerapan tata kelola yang baik atau Good Corporate Governance (GCG). International Financial Corporation (IFC) mendefinisikan GCG sebagai struktur dan proses untuk arah dan kontrol perusahaan, sedangkan Organization for Economic Cooperation and Development (OECD) mendefinisikan GCG sebagai sarana internal untuk mengoperasikan dan mengendalikan perusahaan yang melibatkan hubungan antara manajemen perusahaan, dewan, pemegang saham, dan pemangku kepentingan lainnya (Suri \& Hadad, 2014 ). GCG diperlukan untuk mendorong terciptanya pasar yang efisien, transparan dan konsisten dengan peraturan perundangundangan (KNKG, 2006 ). GCG timbul karena adanya konflik antara manajemen perusahaan sebagai pengelola dengan pemegang saham sebagai pemilik yang kemudian disebut konflik agensi. Konflik agensi timbul karena adanya ketidak percayaan pemegang saham kepada manajemen yang memiliki lebih banyak informasi serta mempunyai kesempatan untuk bertindak diluar kepentingan perusahaan dan pemegang saham.

Jensen and Meckling (1976) menyatakan bahwa hubungan keagenan timbul akibat dari adanya pendelegasian wewenang dari principal (pemilik perusahaan) kepada agent (manajer) dalam rangka melaksanakan operasional perusahaan termasuk pengambilan keputusan. Dalam hal ini Principal mengharapkan agent akan bertindak demi kepentingan principal, dan principal akan memberikan kompensasi baik berupa gaji maupun bonus sebagai imbalan. Namun dalam pelaksanaannya sering terjadi benturan kepentingan antara kepentingan ekonomis perusahaan dalam rangka untuk menyejahterakan principal dengan kepentingan ekonomis pribadi untuk memperkaya individual dari agent (KNKG, 2006). Dalam hal ini, baik principal maupun agent akan sama-sama bersifat untuk 
mementingkan diri sendiri (self interest), dan saling melempar risiko satu sama lain (risk averse) (Eisenhardt, 1989). Chinn (2000) menyampaikan hal yang berlawanan terkait dengan sifat manusia yang self interest dan risk averse. Chinn (2000) menyatakan bahwa manusia pada dasarnya adalah insan yang amanah, jujur dan bertanggung jawab yang hal ini kemudian menjadi asumsi dari teori stewardship. Teori stewardship merupakan sebuah teori yang menjelaskan bahwa manajer sebuah perusahaan merupakan pelayan (steward) yang akan melaksanakan tugasnya mengelola perusahaan demi kepentingan organisasi dan principal atau pemegang saham (Donaldson \& Davis, 1991). Dalam teori stewardship, pengelola sebuah organsisasi akan memiliki motivasi untuk menjalankan tugas dan fungsinya demi kepentingan organisasi dan pemegang saham. Pengelola akan menganggap pendelegasian wewenang yang dilakukan oleh pemilik untuk mengelola perusahaan sebagai sebuah amanah yang harus dijaga dan dilaksanakan dengan penuh tanggung jawab dan integritas yang tinggi.

Kerapan sapi merupakan sebuah budaya khas dari pulau Madura yang memperlombakan kecepatan lari sepasang sapi yang diberi pangonong dan kaleles (Kosim, 2012). Pangonong merupakan sebuah alat yang diletakkan di leher setiap sapi dengan tujuan untuk memasangkan dua sapi, sedangkan kaleles merupakan alat berupa bambu atau kayu yang diikatkan pada pangonong sebagai tempat joki mengendalikan sapi saat dipacu. Joki dalam hal ini biasa disebut sebagai tokang tongko'. Pemilik sapi kerap biasanya memasrahkan sapi kerapnya untuk ditunggangi oleh tokang tongko' untuk dikendalikan sedemikian rupa pada saat pacuan agar sapi kerap dapat berlari maksimal dan memenangkan kompetisi. Pemilik sapi kerap menyadari bahwa tokang tongko' merupakan satusatunya pihak yang dapat mengendalikan sapi pada saat berlari, sehingga pemilik sapi perlu untuk meyakinkan diri bahwa tokang tongko' akan melaksanakan tugasnya dengan amanah, jujur, dan penuh tanggung jawab. Di sisi lain, tokang tongko' akan menunjukkan totalitas yang tinggi dalam melaksanakan perannya untuk mengendalikan sapi kerap. Hal ini terjadi karena tokang tongko' akan ikut bangga apabila sapi kerap yang ditungganginya menjadi pemenang meski pihak yang disorot atas kemenangan sapi kerap bukan tokang tongko', tapi pemilik sapi kerap dan sapi kerap itu sendiri.

Kepercayaan pemilik sapi kerap terhadap tokang tongko', dan sikap tokang tongko' untuk menjalankan tugasnya sebaik mungkin demi kepentingan pemilik sapi kerap, yaitu kecepatan lari sapi kerap yang maksimal dan memenangkan kompetisi memiliki kecocokan dengan teori stewardship yang biasa digunakan sebagai dasar tata kelola perusahaan. Oleh karena itu, tujuan penelitian ini adalah untuk mengkaji bagaimana budaya kerapan sapi masyarakat Madura mampu menjadi metafor pelaksanaan tata kelola perusahaan dari sudut pandang teori stewardship.

\section{METODOLOGI}

Penelitian ini merupakan penelitian kualitatif yang bersifat studi pustaka dengan menggunakan berbagai sumber literatur berupa buku maupun artikel jurnal lainnya yang akan menjadi subjek utama dari penelitian ini. Penelitian ini mengkaji bagaimana ada kemiripan antara kerapan sapi yang merupakan budaya lokal Madura dengan tata kelola perusahaan.

\section{HASIL PEMBAHASAN \\ Tata Kelola Perusahaan dan Teori Stewardship}

Teori stewardship merupakan sebuah teori terkait dengan tata kelola perusahaan dimana dalam teori ini menjelaskan bahwa manajer perusahaan sebagai pengelola akan bertindak demi kepentingan pemilik dan organisasi serta mengesampingkan kepentingan pribadinya (Donaldson \& Davis, 1991). Teori ini mengasumsikan bahwa manajer sebagai pengelola perusahaan memiliki sifat amanah, jujur, dan bertanggung jawab sehingga tidak akan melakukan hal-hal yang akan merugikan pemilik perusahaan (Chinn, 2000).

Teori stewardship merupakan teori yang bertolak belakang dengan teori agency yang menyatakan bahwa manajer sebagai pengelola perusahaan akan mengutamakan kepentingan pribadinya dan oleh karena itu mengesampingkan kepentingan pemilik. Meski demikian, baik teori stewardship maupun teori agency merupakan teori-teori 
yang sering digunakan dalam penelitian tata kelola perusahaan dan sama-sama memiliki landasan serta argumen yang kuat.

Teori stewardship menciptakan dua pihak yang saling berinteraksi untuk menciptakan perusahaan yang kuat yaitu manajer sebagai steward, dan pemilik atau pemegang saham sebagai principal. Terciptanya perusahaan yang kuat baik dari segi organisasi maupun segi ekonomi merupakan bentuk keberhasilan dari hubungan antara steward dan principal yang akan menjadi keuntungan karena perusahaan tersebut akan menciptakan value added. Pada gilirannya, value added yang tercipta dari pengelolaan perusahaan yang baik dan benar akan menciptakan kondisi keuangan perusahaan yang stabil dan menguntungkan. Manajer sebagai steward harus menjaga amanah yang diberikan oleh principal dengan baik dan benar demi tercapainya tujuan perusahaan dalam bentuk kinerja perusahaan yang baik dan menciptakan value added. Manajer harus menyelaraskan tujuannya dengan tujuan principal untuk mencapai kinerja terbaik perusahaan agar mampu bersaing dan memenangkan persaingan dari perusahaan kompetitor.

\section{Kerapan Sapi}

Kerapan sapi merupakan sebuah budaya yang menjadi salah satu ciri khas pulau Madura. Kerapan sapi merupakan kompetisi aduan lari sepasang sapi yang diberi pangonong dan kaleles. Pangonong merupakan alat yang dipasangkan pada leher dua sapi sehingga menjadi satu pasang, sedangkan kaleles merupakan alat tempat joki berdiri untuk mengendalikan laju sapi saat perlombaan. Sapi disebelah kanan disebut sebagai pangloar (bagian luar) dan sapi yang disebelah kiri disebut pangdhelem (bagian dalam). Sapi pangoloar dan pangdhelem memiliki kelebihan dan kekurangan masing-masing, sehingga tugas joki adalah mengatur sedemikian rupa agar pangloar dan pangdhelem dalam kerapan sapi saling melengkapi satu sama lain. Joki memiliki tugas untuk mensinergikan pangloar dan pangdhelem agar performa lari dari sepasang sapi kerap dapat mencapai titik maksimalnya.

Dalam kerapan sapi, pihak-pihak yang terlibat secara langsung adalah pemilik sapi, tokang tongko', tokang ghettak, tokang tambheng, tokang tonjhek, tokang gubra, dan pengibar bendera (Astutik \& Sarmini, 2014; Nurhayati, 2012). Pemilik sapi merupakan pihak yang memiliki sapi kerap dimana motivasi terbesar dari pemilik sapi kerap untuk memiliki sapi kerap adalah hobby dan gengsi (Hasan, 2012), meski tidak dapat dipungkiri bahwa faktor ekonomi dan bisnis juga menjadi salah satu motivasi para pemilik sapi kerap (Juhari, 2016).

Tokang tongko' merupakan joki yang bertugas mengendalikan sapi pada saat sapi sedang dipacu dalam arena balapan. Tokang ghettak merupakan pihak yang bertugas untuk menggertak sapi agar melaju tepat saat bendera start telah dikibarkan. Tokang tonjhek merupakan pihak yang bertugas untuk menarik dan mengarahkan sapi sesuai dengan keinginan pemiliknya. Tokang gubra merupakan pihak yang bertugas untuk memberikan semangat kepada sapi agar lari sapi semakin kencang. Pengibar bendera merupakan pihak yang bertugas untuk memberikan aba-aba untuk memulai kerapan sapi. Dalam kerapan sapi, pemilik sapi akan menunjuk seorang tokang tongko' sebagai pihak yang bertanggung jawab untuk mengendalikan sapi dalam ajang kerapan sapi. Profesionalitas dari seorang tokang tongko' akan mempengaruhi performa dari sapi yang sedang berlari untuk mencapai garis finish dengan cepat dan menjadi pemenang. Hal ini terjadi karena saat sapi berlari, satu-satunya pihak yang mampu mengendalikan sapi adalah tokang tongko' yang sebelumnya telah mendapat amanah dari pemilik sapi.

Dari semua pihak yang terlibat, peran pemilik dan tokang tongko' merupakan peran paling penting dalam rangka memenangkan kompetisi. Pemilik sapi menjadi pihak yang berperan karena pemilik sapi merupakan pihak yang menjadi juragan dan memiliki kuasa tertinggi terhadap sapi kerap, sedangkan tokang tongko' menjadi pihak yang berperan mengendalikan sapi pada saat berlari agar performa lari sapi dapat dimanfaatkan dengan efektif dan efisien. Performa lari sapi yang efektif dan efisien merupakan penentu agar supaya sapi dapat mencapai garis finish dalam waktu secepat mungkin dan menjadi pemenang.

Performa lari sapi dikatakan efektif apabila lari sapi saat perlombaan lurus dan tidak berkelok-kelok, sehingga jarak tempuh yang 
dibutuhkan sapi menuju garis finish menjadi lebih pendek dan lebih cepat. Dalam hal ini, tokang tongko' merupakan satu-satunya pihak yang dapat mengatur lari sapi agar lurus dengan menggunakan kaleles sebagai penentu arah lari sapi. Performa lari sapi dapat efisien apabila tokang tongko' dapat mengangkat kaleles yang ditungganginya seiring gertakan kaki sapi sehingga mengurangi beban sapi dalam menopang tokang tongko' dan pada akhirnya akan mampu berlari dengan lebih ringan dan cepat.

Dalam penunjukan tokang tongko' bisanya terdiri dari dua cara (Astutik \& Sarmini, 2014). Pertama, penunjukan dilakukan dengan cara mendelegasikan tugas tersebut kepada kerabat pemiliki sapi sendiri. Kedua, penunjukan dilakukan dengan mendelagasikan tugas sebagai joki kepada tenaga profesional yang memang menyediakan jasa tokang tongko'. Terlepas dari alternatif mana yang dipilih oleh pemilik sapi, pemilik sapi harus benar-benar yakin bahwa tokang tongko' adalah orang yang jujur, kompeten, dan bertanggung jawab serta mempunyai tujuan yang sama dengan pemilik sapi yaitu menjadikan sapi kerap miliknya sebagai pemenang dalam kompetisi. Hal ini penting karena tidak menutup kemungkinan tokang tongko' yang telah diberi amanah oleh pemilik sapi akan berkhianat karena adanya kecurangan dari pesaing (Juhari, 2016).

\section{Metafor Kerapan Sapi dalam Tata Kelola Perusahaan dari Sudut Pandang Teori Stewardship}

Perusahaan merupakan sebuah organisasi yang dikelola dalam rangka mencapai tujuan yang diharapkan oleh pemilik perusahaan. Dalam praktiknya, sebuah perusahaan akan diatur sedemikian rupa dalam bentuk berbagai strategi bisnis untuk memenangkan persaingan di pasar dan mampu bersaing dengan kompetitor. Pemilik perusahaan atau pemegang saham adalah pihak yang memiliki hak atas asetaset yang dimiliki perusahaan. Dalam perkembangannya, pemilik perusahaan mendelegasikan pihak lain untuk mengelola perusahaan sesuai dengan kepentingan organisasi dan pemilik perusahaan. Pihak yang mendapat mandat ini disebut sebagai manajer perusahaan.
Menurut teori stewardship, manajer dalam sebuah perusahaan merupakan seorang steward atau pelayan yang amanah, jujur, dan bertanggung jawab atas kepercayaan yang telah diberikan oleh pemilik perusahaan untuk mengelola perusahaan. Manajer dalam hal ini akan bekerja semaksimal mungkin dan memandang keberhasilan perusahaan yang dipimpinnya sebagai sebuah tujuan dan kebanggaan baginya, meski perusahaan tersebut bukan miliknya sendiri.

Dalam kerapan sapi, pemilik sapi kerap akan menunjuk joki untuk menjadi pengendali sapi kerap. Pihak yang ditunjuk sebagai joki sapi kerap ini kemudian disebut sebagai tokang tongko'. Telah dijelaskan di atas bahwa pemilik harus benar-benar tepat dalam menunjuk tokang tongko' karena tokang tongko' merupakan pihak yang sangat berperan dalam menentukan performa lari sapi kerap. Banyak hal yang dipertimbangkan oleh pemilik sapi kerap dalam proses pemilihan tokang tonggko' seperti kompetensi, pengalaman, kejujuran, loyalitas, serta sikap tanggung jawab dari calon tokang tongko'. Dalam hal ini, penunjukan tokang tongko' oleh pemilik sapi kerap memiliki kesamaan dengan penunjukan menajer perusahaan oleh pemegang saham melalui Rapat Umum Pemegang Saham (RUPS) yang juga mempertimbangkan banyak faktor seperti kompetensi, pengalaman, dan loyalitas dari calon manajer.

Pemilik perusahaan dalam hal ini mendelegasikan wewenang kepada manajer untuk mengatur perusahaan, begitu juga pemilik sapi kerap yang mendelegasikan wewenang untuk mengatur sapi kerap miliknya kepada tokang tongko'. Selain itu, keinginan dan harapan pemilik perusahaan dengan keinginan dan harapan pemilik sapi kerap juga sama. Keinginan dan harapan pemilik perusahaan adalah agar supaya manajer bekerja dengan baik dan mencapai kinerja perusahaan yang baik dan memenangkan persaingan dalam pasar, begitu juga keinginan dan harapan pemilik sapi kerap agar tokang tongko' menjalankan tugasnya dengan baik dan penuh tanggung jawab agar supaya sapi kerap dapat menunjukkan performa lari terbaik dan menjadi pemenang dari para pesaingnya.

Tokang tongko' memiliki kendali penuh dalam menentukan performa lari sapi kerap 
di arena balapan, layaknya manajer sebuah perusahaan yang memiliki kendali penuh untuk mengarahkan perusahaan yang dikelolanya sesuai dengan keinginannya. Tokang tongko' sangat berpengaruh untuk menentukan kecepatan lari sapi kerap untuk dapat bersaing dengan kompetitorkompetitornya, layaknya manajer perusahaan yang sangat berpengaruh untuk menentukan kinerja sebuah perusahaan agar dapat bersaing dengan kompetitornya.

Sapi kerap di umpamakan sebagai sebuah perusahaan yang sedang beroperasi dimana tokang tongko' yang diumpamakan sebagai manajer perusahaan dapat menentukan efektifitas dan efisiensi kinerja dari sapi kerap untuk mencapai tujuan akhir yaitu kemenangan. Layaknya manajer, tokang tongko' tentu dapat berbuat kecurangan demi kepentingan pribadi dan membuat sapi kerap yang ditungganginya tidak dapat berlari dengan maksimal sehingga akan kalah bersaing dengan kompetitor.

Tokang tongko' dalam bingkai teori stewardship merupakan seorang steward atau pelayan yang memiliki sifat amanah, jujur, dan bertanggung jawab dalam menjalankan tugas yang telah dilimpahkan oleh pemilik sapi kerap sebagai principal, sehingga tujuan dari tokang tongko' bukan semata-mata untuk kepentingan pribadi namun untuk kepentingan pemilik sapi kerap (Astutik \& Sarmini, 2014). Kemenangan sapi kerap dalam perlombaan bukan hanya menjadi tujuan dari pemilik sapi kerap, tapi juga menjadi tujuan dari tokang tongko', meski disisi lain tokang tongko' bisa saja mementingkan diri sendiri dengan tidak membuat sapi kerapnya menang karena adanya sogok-menyogok dari pemilik sapi kerap pesaing (Juhari, 2016). Dalam tata kelola perusahaan yang baik terdapat dewan komisaris yang mengawasi dan mengontrol kinerja manajer dalam melaksanakan tugasnya dalam mengelola perusahaan. Dewan komisaris berfungsi sebagai wakil pemegang saham untuk mengontrol bagaimana semua keputusan yang diambil oleh manajer adalah untuk kepentingan organisasi dan pemegang saham. Dalam kerapan sapi, terdapat tokang gettak dan tokang gubra yang menjadi kontrol kinerja dari sapi kerap untuk tetap berlari kencang terlepas dari peran tokang tongko'. Tokang gettak dan tokang gubra juga merupakan pihak yang secara tidak langsung mengawasi gerak gerik tokang tongko' dilapangan agar benar-benar menjalankan tugasnya untuk mengendalikan sapi kerap dengan baik dan benar.

Pengelolaan yang apik terhadap dua sumber daya utama ini akan menjadi penentu seberapa baik kinerja yang akan dicapai oleh sebuah perusahaan. Dalam kerapan sapi, dua sumber daya dari sapi kerap adalah pangloar dan pangdhelem dari sepasang sapi kerap yang berlari kencang. Pangloar dan pangdhelem memiliki kelebihan dan kekurangan masing-masing, sehingga kepiawaian dari seorang tokang tongko' dalam mensinergikan pangloar dan pangdhelem akan menjadi kunci performa lari sapi kerap yang maksimal.

Pengaturan apik yang diberikan oleh tokang tongko' untuk menyeimbangkan lari sapi pangloar dan pangdhelem akan menjadi penentu performa lari dari sapi kerap yang dipacu. Hal ini menunjukkan bahwa pangloar (sumber daya eksternal) dan pangdhelem (sumber daya internal) dalam sapi kerap (perusahaan) harus diatur sedemikian rupa oleh tokang tongko' (manajer) agar dapat mencapai kinerja sapi kerap (perusahaan) yang maksimal dan memperoleh kemenangan. Kemenangan yang diperoleh akan menciptakan value added dalam wujud harga sapi (harga saham) yang akan meningkat.

Sebagai konsekwensinya, perusahaan yang memiliki kinerja yang baik akan menciptakan value added dengan meningkatnya harga saham perusahaan. Begitu juga adanya pemilik sapi kerap, tokang tongko', tokang gettak, dan tokang gubrak dalam kerapan sapi akan membentuk sebuah mekanisme dalam rangka menciptakan kinerja sapi kerap dalam bentuk performa lari sapi kerap yang maksimal dan mampu bersaing dengan para kompetitor pasangan sapi kerap yang lain. Sebagai konsekwensinya, sapi kerap yang memberikan performa terbaik dan menjadi pemenang juga akan menciptakan value added dengan meningkatnya harga dari sapi kerap itu sendiri. 


\section{KESIMPULAN}

Dalam perusahaan, pemegang saham mendelegasikan wewenang untuk mengelola perusahaan kepada manajer. Dalam teori stewardship, manajer diasumsikan akan menjalankan tugasnya dengan amanah, jujur, dan penuh tanggung jawab demi tercapainya tujuan organisasi dan pemegang saham. Dalam kerapan sapi, pemilik sapi mendelegasikan wewenang untuk mengendalikan sapi kerap untuk dapat berlari dengan maksimal kepada tokang tongko'. Dalam hal ini, pemilik sapi juga berasumsi bahwa tokang tongko' akan menjalankan tugasnya dengan amanah, jujur, serta penuh tanggung jawab demi tercapainya tujuan pemilik sapi kerap.

Tata kelola perusahaan merupakan sebuah hubungan yang terjadi antara pemegang saham, manajemen, dan komisaris serta pihak-pihak lain dalam rangka mewujudkan kinerja perusahaan yang baik untuk menciptakan value added dalam bentuk meningkatknya harga saham perusahaan. Begitu juga kerapan sapi yang di dalamnya ada sinergi antara pemilik sapi kerap, tokang tongko', tokang gettak, tokang gubrak, dan pihak-pihak lain dalam rangka mewujudkan kinerja sapi kerap yang maksimal dan baik untuk menciptakan value added bagi sapi kerap dalam bentuk meningkatnya harga sapi kerap.

Penjelasan di atas menunjukkan bahwa tata kelola perusahaan dalam sudut pandang teori stewardship memiliki kecocokan dengan sebuah budaya khas Madura yaitu kerapan sapi. Tokang tongko' yang diumpamakan sebagai manajer perusahaan memiliki wewenang penuh untuk mengatur dan mengendalikan lari sapi kerap yang diumpamakan sebagai sebuah perusahaan yang sedang beroperasi. Tokang tongko' diasumsikan memiliki sifat amanah, jujur, dan bertanggung jawab dalam bertindak sesuai dengan kepentingan pemilik sapi kerap, yaitu menciptakan performa lari sapi kerap yang baik dan menjadi pemenang selayaknya manajer yang bertindak sesuai dengan kepentingan pemegang saham untuk mewujudkan kinerja terbaik perusahaan dan mampu bersaing dengan perusahaan kompetitor.

\section{DAFTAR PUSTAKA}

Astutik, K. F., \& Sarmini. (2014). Budaya Kerapan Sapi sebagai Modal Sosial Masyarakat Madura di Kecamatan Sepulu Kabupaten Bangkalan. Kajian Moral dan Kewarganegaraan, 3(1), 324-342.

Chinn, R. (2000). Corporate Governance Handbook: Gee Publishing Ltd. London.

Donaldson, L., \& Davis, J. H. (1991). Stewardship theory or agency theory: CEO governance and shareholder returns. Australian Journal of management, 16(1), 49-64.

Eisenhardt, K. M. (1989). Agency Theory: An Assessment and Review. The Academy of Management Review, 14(1), 57-74.

Hasan, F. (2012). Damapk Sosial Ekonomi Pergeseran Nilai Budaya Karapan Sapi. Pamator, 5(2), 96-103.

Jensen, M. C., \& Meckling, W. H. (1976). Theory of The Firm: Managerial Behavior, Agency Costs and Ownership Structure. Journal of Financial Economics 3, 305360.

Juhari, I. B. (2016). Ekonomi dan Prestise dalam Budaya Kerapan Sapi di Madura. Karsa: Journal of Social and Islamic Culture, 24(2), 186-204.

KNKG. (2006). Pedoman Umum Good Corporate Governance Indonesia. Jakarta: Komite Nasional Kebijakan Governance.

Kosim, M. K. M. (2012). Kerapan sapi;"Pesta” rakyat Madura (perspektif historisnormatif). Karsa: Journal of Social and Islamic Culture, 11(1), 68-76.

Nurhayati, A. (2012). Revisiting Pariwisata Madura; Studi Kebijakan Pembangunan Kepariwistaan Kabupaten Sampang. Karsa: Journal of Social and Islamic Culture, 18(2), 182-192.

Suri, S., \& Hadad, M. D. (2014). The Indonesia Corporate Governance Manual First Edition. Jakarta: International Finance Corporation 